\title{
MONOTERPENE EMISSION FROM YOUNG SCOTS PINE MAY BE INFLUENCED BY NUTRIENT AVAILABILITY
}

\author{
MATERIĆ, D. ${ }^{1,2^{*}}$ - BLENKHORN, D. ${ }^{3}$ - GONZÁLEZ-MÉNDEZ, R. ${ }^{3}-$ BRUHN, D $.^{1,4}-$ TURNER, C. ${ }^{5}-$ \\ MORGAN, G. ${ }^{6}-$ MASON, N. ${ }^{6}-$ GAUCI, V. ${ }^{1}$ \\ ${ }^{1}$ School of Environment, Earth and Ecosystems, The Open University \\ Walton Hall, Milton Keynes, MK7 6AA, United Kingdom \\ (phone: +44(0)1908332454,; fax: +44(0)1908655151) \\ ${ }^{2}$ Institute for Marine and Atmospheric Research, Utrecht University \\ 3584CC Utrecht, The Netherlands \\ ${ }^{3}$ School of Physics and Astronomy, University of Birmingham \\ Edgbaston, Birmingham, B15 2TT, United Kingdom \\ ${ }^{4}$ Department of Chemistry and Bioscience, Aalborg University \\ Fredrik Bajers Vej 7H, 9220 Aalborg East, Denmark \\ ${ }^{5}$ School of Life, Health and Chemical Sciences, The Open University \\ Walton Hall, Milton Keynes, MK7 6AA, United Kingdom \\ ${ }^{6}$ School of Physical Sciences, The Open University \\ Walton Hall, Milton Keynes, MK7 6AA, United Kingdom \\ *Corresponding author \\ e-mail:dusan.materic@gmail.com \\ (phone: +31(0)302-537-758; fax: +44(0)190-865-5151) \\ (Received $20^{\text {th }}$ Oct 2015; accepted $3^{\text {rd }}$ Oct 2016)
}

\begin{abstract}
Monoterpenes $\left(\mathrm{C}_{10} \mathrm{H}_{16}\right)$ are the products of metabolism found in many plants and are most notably emitted by conifers. Many abiotic and biotic factors are known to stimulate monoterpene emissions from conifers, including: temperature, wounding, herbivory, infestation, UV-radiation, $\mathrm{O}_{3}$ exposure etc. Monoterpenes have been shown to contribute to aerosol and cloud formation, which have a net cooling effect on Earth's radiative balance. Thus, there is a need to explore all the factors that influence monoterpene emissions from forests. One as yet largely unexplored process is the effect of nutrient availability on monoterpene emission. In this study we treated young Scots pine seedlings with fertilizer (NPK and urea) largely and observed a large increase in monoterpene emission compared with unfertilized controls. Measurements at $26^{\circ} \mathrm{C}$ suggests an emission increase of $0.8 \mathrm{ng} \mathrm{g}^{-1} \mathrm{DW} \mathrm{min}^{-1}$ per addition of $1 \mathrm{~kg} \mathrm{~N}_{\text {tot }}$ ha $^{-1}$ year $^{-1}$. These results are important for understanding future trends in monoterpene emission, since nitrogen deposition, as consequence of industrial emissions and agricultural sources, is increasing in the soils of boreal and high altitude temperate forests.
\end{abstract}

Keywords: GC-MS; NPK; Pinus sylvestris; PTR-MS; VOC

\section{Introduction}

Plants emit a variety of volatile organic compounds (VOCs), of which isoprene and the monoterpenes are the most abundant (Arneth et al., 2008; Guenther et al., 2006; Räisänen et al., 2009). The major source of monoterpene $\left(\mathrm{C}_{10} \mathrm{H}_{16}\right)$ emissions into the atmosphere is conifer plants, predominantly growing in the boreal zone, but also growing extensively in temperate regions. The annual emission rate of monoterpenes from a boreal forest is estimated to be $0.71 \mathrm{t} \mathrm{km}^{-2}$ (Räisänen et al., 2009; Guenther et al., 
1993). Monoterpenes are known to contribute to aerosol formation, via their oxidation by $\mathrm{NO}_{\mathrm{x}}, \mathrm{O}_{3}$ and $\mathrm{OH}$, producing numerous oxidation products, which serve as cloud nuclei in cloud formation (Hoffmann et al., 1997; Lee et al., 2006) which, in turn, in turn leads to a cooling effect of Earth (Peñuelas and Staudt, 2010).

Many abiotic and biotic factors influence conifer monoterpene emission, but the most critical are the ambient temperature and the monoterpene pool in plant tissue (Räisänen et al., 2009; Tingey et al., 1980). Wounding, herbivore infestation, ozone concentrations and UV exposure have all been shown to stimulate monoterpene emission rates (Blande et al., 2009; Holopainen and Gershenzon, 2010; Loreto et al., 2006; Räisänen et al., 2009; Yuan et al., 2009).

However, one abiotic factor that, to date, has been largely overlooked in the context of plant VOC emission is the effect of changing the availability of nutrients within the soil. It has been shown that nutrient availability plays an important role in some VOC emissions, more so than other factors in multiple stress conditions (Peñuelas and Staudt, 2010). Plants have a fast response to the introduction of nitrogen $(\mathrm{N})$ based fertilizers, which stimulate both biomass production and photosynthesis in conifers (Brix, 1971). Furthermore, the introduction of a N-based fertiliser in boreal forests increases ultrastructural changes in cells (sub-cellular and sub-organellar), especially those related to photosynthesis, such as thylakoids and grains of plastids (Soikkeli and Kärenlampi, 1984).

Terrestrial ecosystems are adapted to low soil fertility and low availability of $\mathrm{N}$, thus anthropogenic $\mathrm{N}$ enrichment can have many effects on ecosystems, including a change in species composition, a change in tree physiology and a lowering of tree resilience to frost (Bobbink et al., 2010; Soikkeli and Kärenlampi, 1984; Soja et al., 2007).

An increase in industrialization and modern agriculture has brought artificial fertilization of the soil in the form of $\mathrm{N}$ deposition. In the temporal zone, the $\mathrm{N}$ deposition rate has been estimated to be $1-100 \mathrm{~kg} \mathrm{~N} \mathrm{Ha}^{-1}$ year $^{-1}$, depending on the level of $\mathrm{N}$ emission in the area (Bobbink et al., 2010; Högberg et al., 2006; Soikkeli and Kärenlampi, 1984). In the boreal zone, the $\mathrm{N}$ deposition rate is generally considered to be lower than $6 \mathrm{~kg} \mathrm{~N} \mathrm{Ha}^{-1}$ year ${ }^{-1}$, but with an increasing trend (Bobbink et al., 2010).

In this paper both semi-quantitative and qualitative differences in monoterpene emissions are investigated as a consequence of fertilization treatments of young Scots pine trees.

\section{Materials and methods}

\section{Experimental application of NPK fertilizer}

\section{Growing conditions}

Two year old, 10-20 cm high Scots pine trees (Pinus silvestris L.) were obtained from a local tree nursery (Buckingham Nurseries and Garden Centre, Milton Keynes, UK) and potted in topsoil in the early spring (12 in total, 6 for each treatment). The trees were grown outside, watered equally and regularly (once per week). Half of the trees were treated twice (April and Jun) with a slow releasing fertiliser NPK 7-7-7 $(7 \% \mathrm{~N}, 7 \% \mathrm{P}$ and $7 \% \mathrm{~K})$, at a rate equal to $140 \mathrm{~kg} \mathrm{~N}_{\text {tot }}$ ha $^{-1}$ year ${ }^{-1}$, with the other half being untreated and used as control specimens. The base level of total nitrogen in the soil was measured by modified Kjeldahl analysis (British Standards Institute, 2001). This high level treatment has been chosen for this study in order to establish the 
presence of a fertilizer effect on monoterpene emissions. The plants were divided into two groups of 6 plants ( 3 treatment and 3 controls in each group), and VOCs were analysed by Proton Transfer Reaction-Time of Flight-Mass Spectrometry (PTR-ToFMS) and Thermal Desorption-Gas Chromatography-Mass Spectrometry (TD-GC-MS) (Materić et al., 2015).

\section{Plant enclosure and PTR-ToF-MS measurement}

A ring of PTFE (Polytetrafluoroethylene) tape was wrapped around the plant branch in the location where sampling cuvettes were sited. The end of the leaf cuvette was filled with a PTFE-coated sponge, to provide a gas tight seal without damaging the tree. Each day we measured the emission from two different plants (one fertilized and one control, chosen randomly), 6 plants in total were analysed in this experiment.

A branch from each plant was enclosed overnight in a PTFE leaf cuvette with a quartz glass window (Figure 1) and flushed with purified air at a rate of $250 \mathrm{ml} \mathrm{min}^{-1}$. An artificial light source was installed above the plants to give $450 \mu \mathrm{mol}$ photons $\mathrm{m}^{-2} \mathrm{~s}^{-1}$ photosynthetically active radiation (PAR, 400-700 $\mathrm{nm}$ ) during VOC measurements, in order to stimulate photosynthesis. Measurements were started with the lights off for 30 minutes in order to see the difference in the emission when the temperature conditions changed. The temperature at the start of the experiment was on average $23.5^{\circ} \mathrm{C}$. When the light was turned on, the temperature increased to a maximum of around $32{ }^{\circ} \mathrm{C}$. Measurements were continued at $32^{\circ} \mathrm{C}$ for $3 \mathrm{~h}$.


Figure 1. Leaf cuvette design and automated VOCs sampling set up, for simultaneous VOC measurement from 6 lines (five plants and a background) 
Monoterpene emission rates were measured at m/z 137 using a PTR-ToF-MS, (Kore Technology Limited, UK). The mass range used was from $\mathrm{m} / \mathrm{z} 15$ to 334 and $E / N$ (the ratio of the electric field strength $E$ and the gas number density $N$; in effect it is a collision energy applied to the ion-molecules) was set to $140 \mathrm{Td}\left(1 \mathrm{Td}=10^{-21} \mathrm{~V} \mathrm{~m}^{2}\right)$. A four minute cycle was used for each measurement. The system was then flushed for one minute between the measurements, the sampling sequence being controlled using solenoid valves. The cuvettes were tested for any memory effect and blank tests were conducted on the pure air.

\section{Plant enclosure and TD-GC-MS measurement}

For TD-GC-MS measurements, each day 2 plants were enclosed as described above in the leaf cuvettes at 11:30 h, and pumped with purified air at an average flow rate of $250 \mathrm{ml} \mathrm{min}{ }^{-1}$. A different set of 6 plants ( 3 treatments and 3 controls) were used for the TD-GC-MS experiment. VOCs were removed from the inlet air using a hydrocarbon trap. Flow meters (Cole-Parmer, UK) were used to determine the flow rates; temperature and light conditions were measured and logged during the experiment. The enclosures were flushed with the clean air for 2 hours before starting the sample collection. Samples were collected by passing the air across sorbent tubes packed with Tenax II/Sulficarb (Markes International Ltd, UK) for 2 hours, at the same flow rate. The tubes were stored at $4^{\circ} \mathrm{C}$ for no more than a week before the analysis.

We used TD-GC-MS in order to determine the relative abundances of the individual monoterpenes. A 6890-5973 GC-MS (Agilent Technologies, Stockport, UK) fitted with a thermal desorption unit and an autosampler (Unity2 and Ultra 50:50, Markes International Ltd, UK) was used. TD tubes were desorbed for 3 minutes, at $260^{\circ} \mathrm{C}$, onto a cold trap set at $-7^{\circ} \mathrm{C}$. The cold trap was then heated at a maximum rate $\left(>40^{\circ} \mathrm{C} \mathrm{s}^{-1}\right)$ until $300^{\circ} \mathrm{C}$ was reached. The sample was separated on a Rxi-624SilMS (Thames Restek, UK), $60 \mathrm{~m}$ capilarry column $(1.8 \mu \mathrm{m}$ film tickness) with the following temperature ramp settings: $35^{\circ} \mathrm{C}$ for $5 \mathrm{~min}, 11^{\circ} \mathrm{C} / \mathrm{min}$ ramp up to $60^{\circ} \mathrm{C}, 20^{\circ} \mathrm{C} / \mathrm{min}$ ramp up to $220^{\circ} \mathrm{C}$. The temperature was kept at $220^{\circ} \mathrm{C}$ until the end of the run. We used helium as a carier gas and constant pressure $14.72 \mathrm{psi}$, resulting an initial flow of $2.4 \mathrm{ml} / \mathrm{min}$.

\section{Data analysis}

PTR-ToF-MS spectra were analysed using a PeakCalc script (https://github.com/dusanac/PeakCalc), which utilizes normalization of background subtracted analyte (m/z 137) to one million primary ions (the sum of $\mathrm{H}_{3} \mathrm{O}^{+}, \mathrm{H}_{2} \mathrm{O} . \mathrm{H}_{3} \mathrm{O}^{+}$, and $\left.\left(\mathrm{H}_{2} \mathrm{O}\right)_{2} \cdot \mathrm{H}_{3} \mathrm{O}^{+}\right)$. The concentrations were calculated by a Perl script (Script S1), which takes raw the measurement parameters and calculates the concentrations in ppbv, based on the work of (Cappellin et al., 2012). In order to determine the flux, the concentrations measured by PTR-ToF-MS were normalized to the leaf surface area of the plants and the flow rate. We used the instrument parameters, measurement conditions, and monoterpene $k$ rate of $2.2 \times 10^{-9} \mathrm{~cm}^{3} \mathrm{~s}^{-1}$ in order to calculate the concentration of monoterpenes as described earlier (Tani et al., 2003). Leaf areas were estimated using the program ImageJ (www.imagej.net), and the projected specific leaf area of $0.005 \mathrm{~m}^{2} \mathrm{~g}^{-1}\left(0.01 \mathrm{~m}^{2} \mathrm{~g}^{-1}\right.$ total leaf are $)$ was used to convert leaf area to mass (Aalto et al., 2014). We used the emission values after the temperature reached and stabilized at $32^{\circ} \mathrm{C}$, and tested the logarithmic responses (log-transformed) of the 
emissions for statistical difference by $t$ test in $R$. All the figures presented were generated using SigmaPlot software (v12.0).

Monoterpenes were identified on the TD-GS-MS using the AMDIS 2.70 program, and their peak areas were integrated using ChemStation (Agilent Techologies, Stockport, UK).

\section{Experiments with nitrogen-based fertilizer}

\section{Growing conditions}

One-year-old Scots pine (Pinus sylvestris L.) seedlings were potted in round pots (10.5 $\mathrm{cm}$ in diameter) in the early spring (at the beginning of April). The seedlings were randomly divided into 5 groups ( 5 plants per group), and each group treated with a different simulated deposition rate of urea $\left(\mathrm{NH}_{2} \mathrm{CONH}_{2}\right)$ equivalent to $0,10,25,50$ and $100 \mathrm{Kg} \mathrm{Ha}^{-1}$ year ${ }^{-1}$. The base value of total nitrogen in soil was measured by modified Kjeldahl analysis (British Standards Institute, 2001). The fertilizer was applied in six discrete treatments every second week until the end of June. The VOC measurements were carried out in August, allowing enough time for the plant to assimilate the nitrogen from the fertilizer.

\section{Automated sampling system design}

An automated sampling system, based on an Arduino Uno microcontroller, was developed allowing sampling from 6 lines in sequence (5 plants enclosed in leaf cuvettes and one background air line) (Figure 1). The microcontroller has been programmed to send the $5 \mathrm{~V}$ signal in the 5 minute time sequence (Script S2). An electronic board has been developed for each line in order to amplify the $5 \mathrm{~V}$ signal (the output voltage of Arduino Uno) into $24 \mathrm{~V}$, this is used to control switching of the solenoid valves. In order to control the sampling each gas line required a solenoid valve and an electronic board. The detailed description of the electronic board and wiring can be found in Figure 1. The developed sampling system is robust and could be extended to control more than six sampling lines (up to 14 lines with Arduino Uno, and up to 54 lines with Arduino Mega). A 5 minute sampling time was used for each line (one minute for flushing and 4 minutes for VOC sampling), thus each complete sequence (5 plants and one background air) was 30 minutes long.

\section{Cuvette design}

PTFE leaf cuvettes have been designed and constructed for this and subsequent experiments (Figure 1). A cuvette was designed to have all internal surfaces made of PTFE (except the glass window). The upper and lower part of a cuvette connect via two PTFE coated silicon sponges which are inserted in the upper and lower part grids. This way a soft, gas-tight connection with the plant branch is achieved and the stress during the enclosure is minimised.

\section{Plant enclosure and PTR-ToF-MS measurements}

Plants were enclosed for one night prior to the PTR-MS analysis during which the system was flushed with the clean air at a rate of $0.5 \mathrm{~L} \mathrm{~min}^{-1}$. Clean air was provided by scrubbing air through a filter containing a hydrocarbon trap. The analysis was carried 
out under artificial light conditions of $200 \mu \mathrm{mol} \mathrm{m} \mathrm{m}^{-2} \mathrm{~s}^{-1}$ (400-700 nm, PAR) and leaf temperature of $26^{\circ} \mathrm{C}( \pm 1.5)$, which were measured by a PAR meter and thermocouples.

PTR-ToF-MS measurements were carried out at $140 \mathrm{E} / \mathrm{N}$ with a hollow cathode pressure of $1.3 \mathrm{mBar}$, drift tube pressure of $1 \mathrm{mBar}$, drift tube temperature of $100^{\circ} \mathrm{C}$, mass range $15-240 \mathrm{~m} / \mathrm{z}$, and time resolution of 4 minutes. Analysis was carried out for at least 2 hours ( 4 cycles) in order to obtain a good average signal for each plant and background.

After VOC analysis the enclosed branches were harvested. Needles were dried for 20 hours at $60^{\circ} \mathrm{C}$, and the dry weight (DW) was measured. The foliar total nitrogen content was estimated by modified Kjeldahl analysis (British Standards Institute, 2001).

\section{Sampling and GC-MS measurement}

After PTR-MS analysis fresh needles were collected and cut into $5 \mathrm{~mm}$ long sections with clean sharp scissors. Then $0.5 \mathrm{~g}$ of cut needles were mixed with $0.5 \mathrm{~mL}$ of hexane and incubated at room temperature overnight in order to extract all monoterpenes, as previously suggested (Thoss et al., 2007). After the incubation the liquid solution was transferred to $1 \mathrm{~mL}$ GC vials and GC-MS was performed with Agilent 5973, using a 30 $\mathrm{m}$, HP-5 capillary column, $0.25 \mathrm{~mm}$ diameter, $0.25 \mu \mathrm{m}$ film thickness (Agilent 19091S433). $1 \mu 1$ of the sample was loaded, the inlet temperature was set to $250^{\circ} \mathrm{C}$, and a split ratio of 50:1 was used. The oven temperature set up was: $35^{\circ} \mathrm{C}$ initial temperature for 1 min, increasing at rate $4^{\circ} \mathrm{C} / \mathrm{min}$ until $140^{\circ} \mathrm{C}$ was reached, then $45^{\circ} \mathrm{C} / \mathrm{min}$ until $200^{\circ} \mathrm{C}$, holding at the final temperature for 5 minutes (Räisänen et al., 2009).

The GC-MS instrument was calibrated using a standard dilution of $\alpha$-pinene, camphene, 3-carene, and limonene $(2,5,10$ and $100 \mathrm{ng} / \mu \mathrm{L})$. Quantification for $\beta$ pinene and myrcene was performed using the average monoterpenes calibration line.

\section{Data analysis}

PTR-ToF-MS spectra were analysed by PeakExtract (Kore Technologies, UK). In order to calculate the flux, the signal of $\mathrm{m} / \mathrm{z} 81$ and $\mathrm{m} / \mathrm{z} 137$ was normalised to one million reagent ions of $\mathrm{H}_{3} \mathrm{O}^{+}$(measured at isotope mass 21 ), and water hydronium water clusters $\mathrm{H}_{2} \mathrm{O} \cdot \mathrm{H}_{3} \mathrm{O}^{+}$, and $\mathrm{H}_{2} \mathrm{O} \cdot \mathrm{H}_{2} \mathrm{O} \cdot \mathrm{H}_{3} \mathrm{O}^{+}$(at $\mathrm{m} / \mathrm{z} \mathrm{39}$, and $\mathrm{m} / \mathrm{z} 55$ ). The instrument parameters, measurement conditions, and monoterpene $k$ rate of $2.2 \times 10^{-9} \mathrm{~cm}^{3} \mathrm{~s}^{-1}$ were used to calculate the concentration of monoterpenes as described earlier (section 2.2.3; Script 4, Appendix A) (Tani et al., 2003). The statistical significance of logarithmic responses of the emissions was tested by t-test in $R$, and the data were visualized using SigmaPlot 13.

GC-MS peak integration was performed using ChemStation. Statistical differences were tested in $R$ (t-test), and the data were visualized using SigmaPlot 13.

\section{Results}

\section{Experimental application of NPK fertilizer}

At the beginning of the experiment there was $0.28 \%$ of the total nitrogen in the soil. The emission rates of monoterpenes in the NPK treatment group were 13 times higher than those from the controls $(\mathrm{p}<0.01)$ (Figure 2 and 3). The data also showed that monoterpene emissions responded immediately to the increase of the temperature in the cuvettes (from 23 to $30^{\circ} \mathrm{C}$; Figure 2), which is in agreement with previous studies 
(Guenther et al., 1993; Loreto and Schnitzler, 2010; Räisänen et al., 2009; Tingey et al., 1980). High flux variations were observed between plants from each treatment group (Figure 3). No memory effects (carry over) of monoterpenes have been observed in our enclosure system.

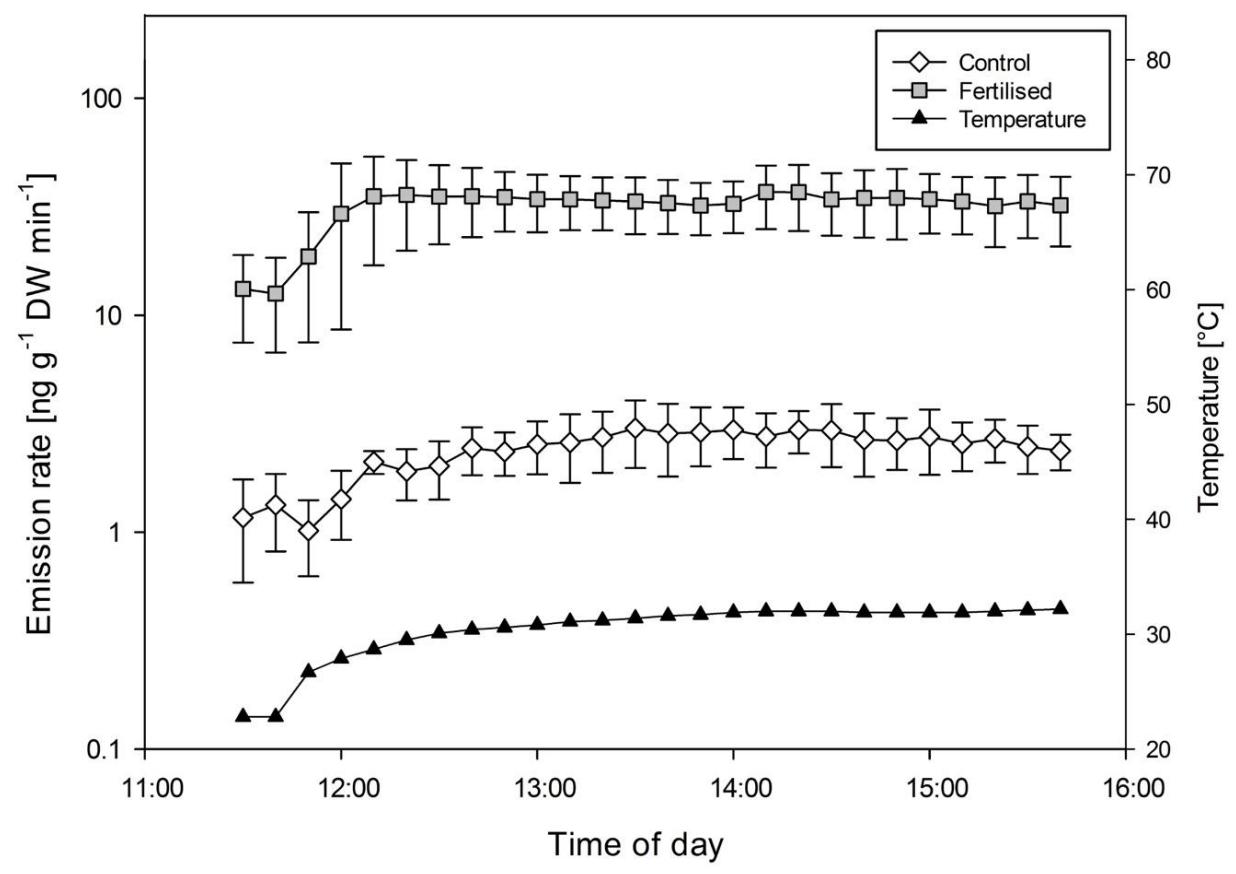

Figure 2. Monoterpene emission rates of fertilized (140 $\mathrm{kg}_{\text {tot }} \mathrm{ha}^{-1}$ year $\left.{ }^{-1}\right)$ and control group (measured by PTR-ToF-MS) and its relation to the temperature ramp. Note the logarithmic scale ( $x$ axes). Each treatment: $n=3$, error bars $=S E$



Figure 3. Overall monoterpene flux between the treatment (NPK $140 \mathrm{~kg} \mathrm{~N}_{\text {tot }} \mathrm{ha}^{-1}$ year $\left.{ }^{-1}\right)$ and control measured by PTR-ToF-MS. Each treatment: $n=3$, error bars $=S E$, fertilized mean $=$ 33.9, control mean $=2.6$. The emissions are significantly different (t-test, $p<0.01)$. 
The light intensity during the laboratory experiment ( $450 \mu \mathrm{mol}$ photons $\mathrm{m}^{-2} \mathrm{~s}^{-1}$ PAR) was lower than the average value measured at the growing site, where we observed fluctuations between 350 and $1600 \mu \mathrm{mol}$ photons $\mathrm{m}^{-2} \mathrm{~s}^{-1}$ PAR (cloudy conditions to full sun).

Analysis by TD-GC-MS reveal differences in the composition of monoterpenes emitted from fertilized and untreated plants (Figure 4). Fertilized plants were seen to emit much lower amounts limonene. On the other hand, NPK-treatment seem to induce higher abundances of camphene, myrcene and both pinenes, although the differences are not statistically significant.

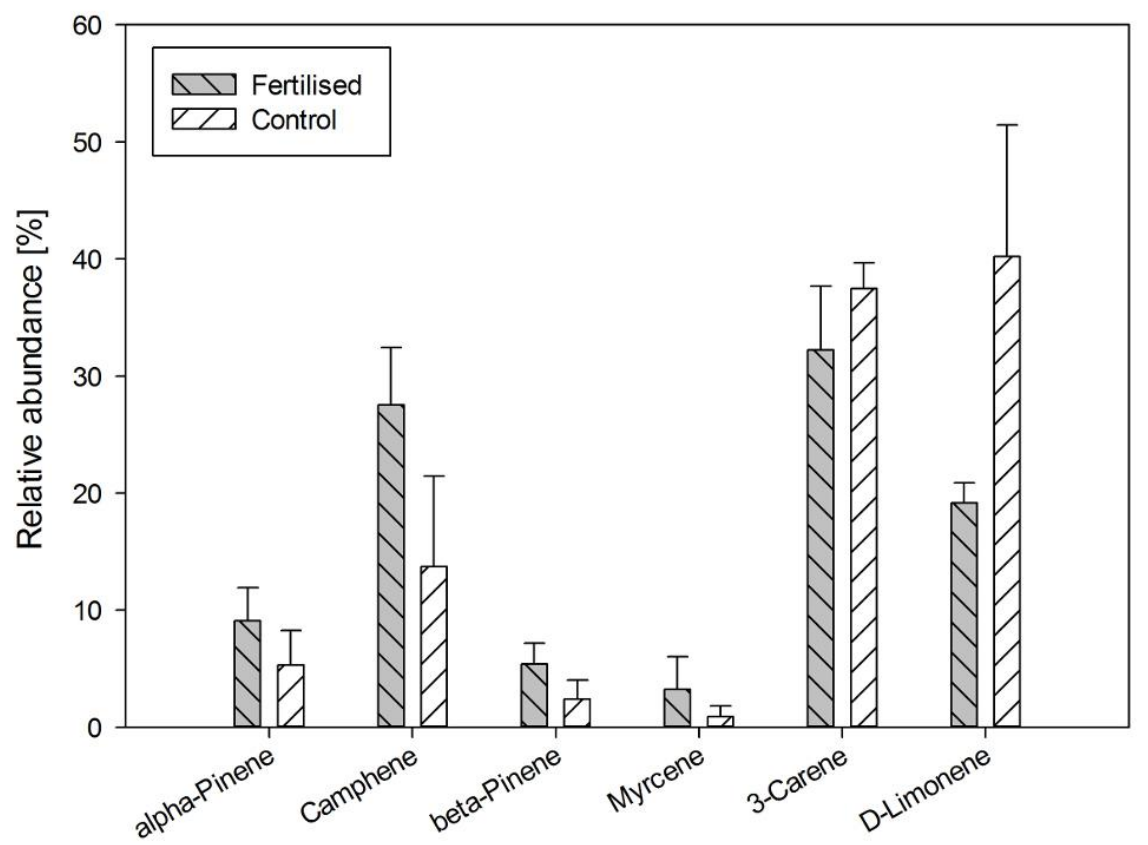

Figure 4. Difference in relative abundance of individual monoterpenes between treatments as measured by TD-GC-MS. Each treatment: $n=3$, error bars $=S E$. No significant difference was found between treatment and control.

\section{Experimental addition of nitrogen based fertilizer}

For this experiment the initial total nitrogen content in the soil (prior to treatment application) was $0.51 \%$. There was an increasing trend of total foliar nitrogen in respect to increased urea treatment (Figure 5), but there was no statistically significant difference between the groups.

The change in monoterpene emissions as a consequence of $\mathrm{N}$-fertilizer treatment is shown in (Figure 6). The emission linearly increased from $4 \mathrm{ng} \mathrm{g}^{-1} \mathrm{DW} \mathrm{min}^{-1}$ for the control, to $44 \mathrm{ng} \mathrm{g}^{-1} \mathrm{DW} \mathrm{min}{ }^{-1}$ for the treatment of $50 \mathrm{Kg} \mathrm{Ha}^{-1}$ year ${ }^{-1}$, after which for the treatment of $100 \mathrm{Kg} \mathrm{Ha}^{-1}$ year ${ }^{-1}$ emission drops to $29 \mathrm{ng} \mathrm{g}^{-1} \mathrm{DW} \mathrm{min}{ }^{-1}$. Analysis of variances with one-way ANOVA showed a statistically significant difference $(p<0.01)$. It is notable that even the lowest fertilizer treatment of $10 \mathrm{Kg} \mathrm{Ha}^{-1} \mathrm{year}^{-1}$ resulted in a 5fold increase of monoterpene emission. 


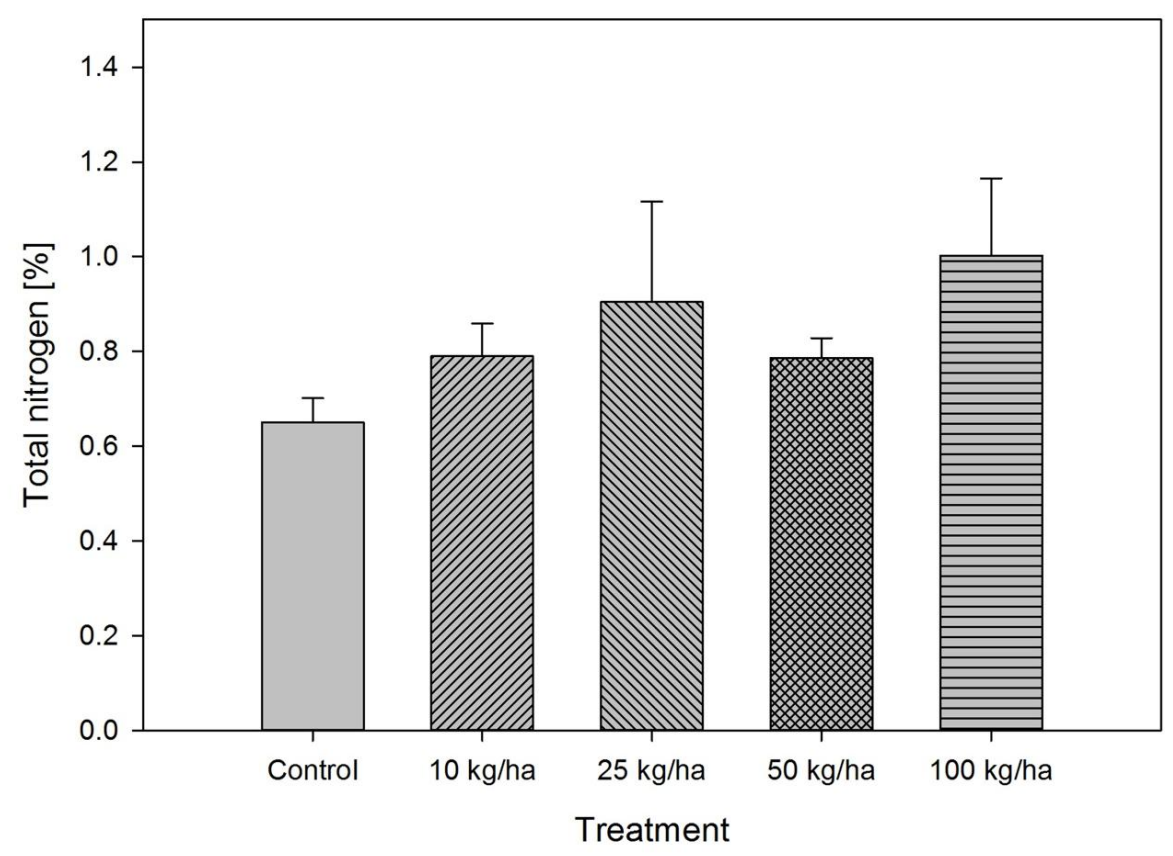

Figure 5. Total nitrogen content in pine needles. Each treatment: $n=4$ (except $50 \mathrm{Kg} / \mathrm{ha}$ treatment, $n=5$ ), error bars $=S E$. There was no significant treatment effect.

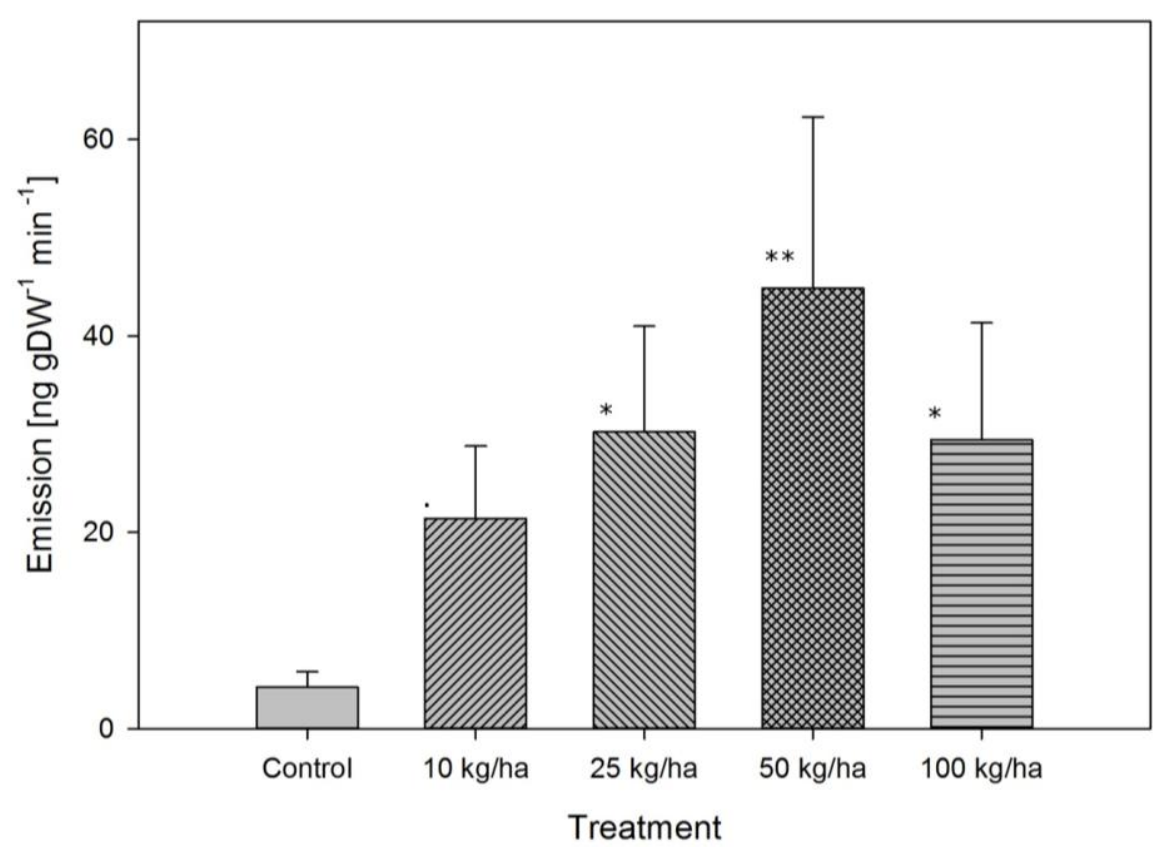

Figure 6. Monoterpene emissions from Scots pine as measured by PTR-ToF-MS. Each treatment: $n=4$ (except $50 \mathrm{Kg} / \mathrm{ha}$ treatment, $n=5$ ), error bars $=S E$. Tukey test shows that significant differences $(p<0.05)$ lay between the control and each of the treatments except 10 $\mathrm{kg} / \mathrm{ha}$ (significance levels: 0.001 '**'0.01 '*’ 0.05 '’ 0.1 ) 
On the other hand, no significant change in the total amount of monoterpenes in leaf tissue was observed, as analysed by GC-MS (Figure 7). No significant changes in the relative content of individual monoterpenes were detected as a function of treatment (Figure 8).

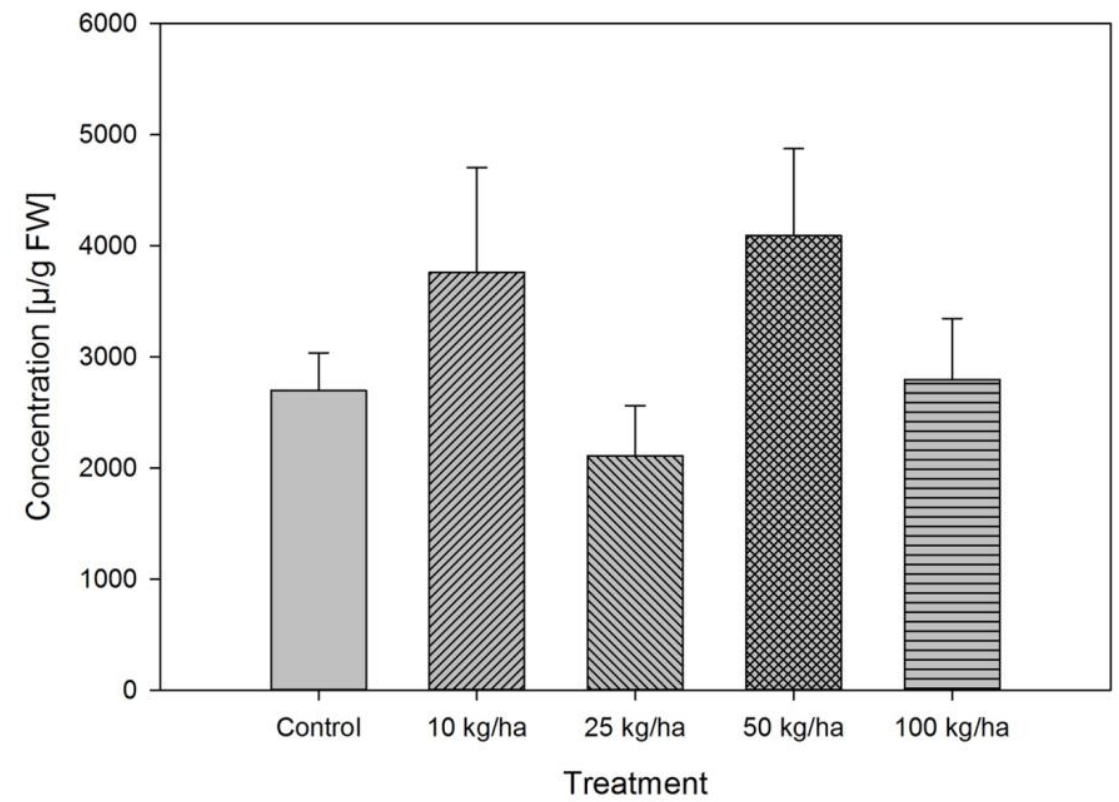

Figure 7. Total monoterpene content in Scots pine needles as measured by GC-MS. Each treatment: $n=5$ (except $100 \mathrm{Kg} / \mathrm{ha}$ treatment, $n=4$ ), error bars $=S E$. No significant difference found

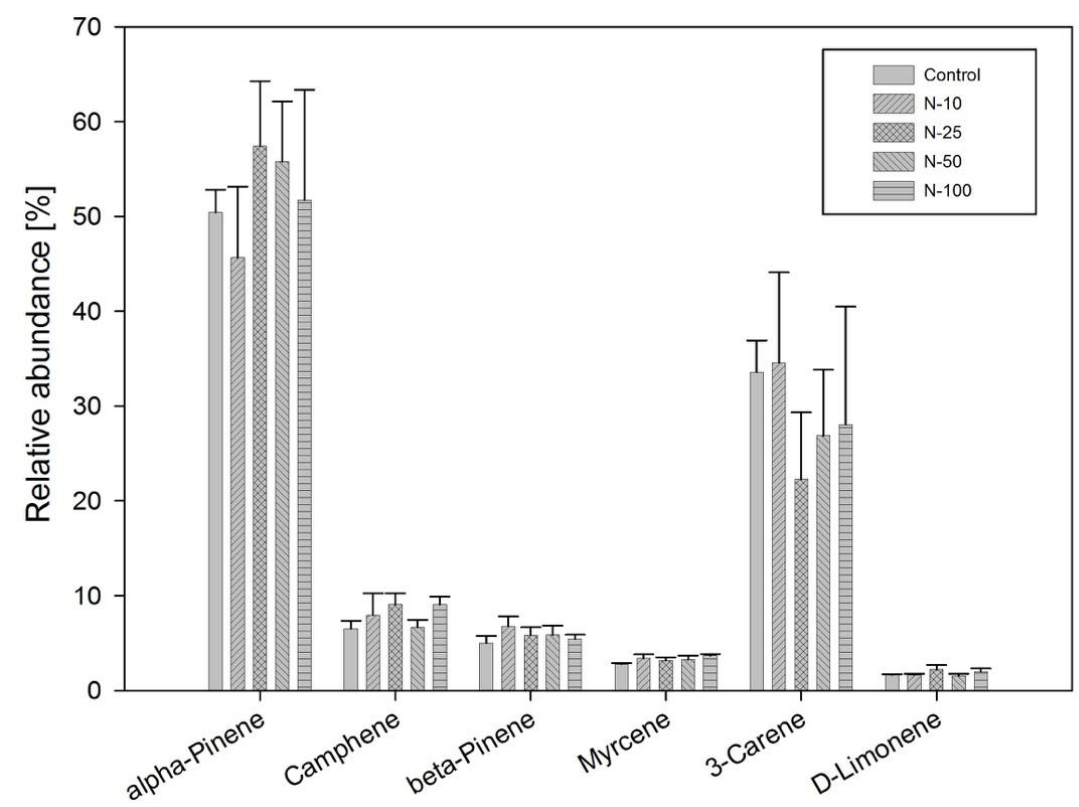

Figure 8. Relative concentration of individual monoterpenes in Scots pine needles treated with different levels of $\mathrm{N}$ measured by $\mathrm{GC}-\mathrm{MS}$. Each treatment: $n=5$ (except $100 \mathrm{Kg} / \mathrm{ha}$ treatment, $n=4)$, error bars $=$ SE. No significant difference was found between the different levels of $N$ treatment. 


\section{Discussion}

It has been reported that treatment with $\mathrm{N}$ based fertilizer increases the photosynthesis rate and results in higher biomass production in conifers (Brix, 1971). Cell ultra-structural observations in Scots pines and Norway spruces have shown an increase in the proportion of tick grana and higher thylakoid index in fertilized plants (Soikkeli and Kärenlampi, 1984). However, this effect has not yet been studied with respect to VOC emissions.

In both experiments reported here (treatment with NPK and treatment with N-based fertiliser) a statistically significant influence on monoterpene emissions between treatment groups was observed, which is in agreement with previous work on Pinus pinaster (Blanch et al., 2012). We have tentatively attributed this to the fertiliser treatment. We were unable to measure photosynthesis parameters; however, we do not expect photosynthetic effects to significantly influence emissions reported here as the light conditions during the measuremtn have been constant. Also the pines are pool emitters and the monoterpene emission is more temperature then light dependent, although some enantiomes in certain cicrcumstances showed to have slight light dependance (Aalto et al., 2015; Peñuelas and Llusià, 2001; Räisänen et al., 2009; Yassaa and Williams, 2007). The effect of nutrient addition on monoterpene emissions may be explained either as a consequence of a higher level of monoterpene synthesis in the plant tissue or as a result of high nutrient stress (not just with high inputs of nitrogen, but $\mathrm{P}$ and $\mathrm{K}$ as well). It has been reported that higher availability of phosphorus may also increase the emission of monoterpenes, which was shown for Pinus pinaster treated with different phosphorus levels when concentrations of N, K, $\mathrm{Mg}$ and Ca were kept at optimal levels (Blanch et al., 2012).

The experiments with $\mathrm{N}$-based fertilizer (urea) and more representative levels of treatment showed that even the lower amounts of $\mathrm{N}$ input, $\left(10,25,50 \mathrm{Kg} \mathrm{Ha}^{-1}\right.$ year $^{-1}$ ) affected the monoterpene emission (by 5, 7, 10 - fold respectively). It is hypothesised that the higher emission rates of monoterpenes observed in these treatments might come as a consequence of higher rates of monoterpene synthesis due the presence of fertilizer, however this needs to be confirmed experimentally.

PTR-ToF-MS data showed a linear increase in monoterpene emission with treatment up to $50 \mathrm{Kg} \mathrm{Ha}^{-1}$ year $^{-1}$, after which a slight drop in emission was observed (Figure 6). The emission increases $0.8 \mathrm{ng} \mathrm{g}^{-1} \mathrm{DW} \min ^{-1}$ per addition of $1 \mathrm{~kg} \mathrm{~N}_{\text {tot }}$ ha $^{-1}$ year ${ }^{-1}$ (measured at $26^{\circ} \mathrm{C}, \mathrm{R}^{2}=0.94$ ). The drop in the emission when a high dosage of fertilizer is applied $\left(>50 \mathrm{Kg} \mathrm{Ha}^{-1}\right.$ year $\left.^{-1}\right)$ suggests that there is a threshold at which overfertilization suppresses any further increase in monoterpene production and emission.

Accordingly, an equation describing the effect of nitrogen addition on monoterpene emission $\left(<50 \mathrm{ng} \mathrm{g}^{-1} \mathrm{DW} \mathrm{min}^{-1}, 26^{\circ} \mathrm{C}\right)$ may be written as:

$$
E_{p}=\left(N_{p}-N_{M}\right) \times k_{N}+E_{M}
$$

where $E_{P}$ is predicted monoterpene emission in $\mathrm{ng} \mathrm{g}^{-1} \mathrm{DW} \min ^{-1}, \mathrm{~N}_{\mathrm{P}}$ is the predicted addition of nitrogen in $\mathrm{kg} \mathrm{N}_{\text {tot }}$ ha $^{-1}$ year ${ }^{-1}$, and $\mathrm{N}_{\mathrm{M}}$ is actual nitrogen added to the plant from which the emission is measured in $\mathrm{kg} \mathrm{N}_{\text {tot }} \mathrm{ha}^{-1}$ year ${ }^{-1}, k_{N}$ is an experimentally determined coefficient (a slope) describing how much change in monoterpene emission occurs when $1 \mathrm{~kg} \mathrm{~N}_{\text {tot }}$ ha $^{-1}$ year ${ }^{-1}$ is added $\left(0.8 \mathrm{ng} \mathrm{g}^{-1} \mathrm{DW} \mathrm{min} \mathrm{mg}^{-1} \mathrm{~N}_{\text {tot }}\right.$ ha year at $26^{\circ} \mathrm{C}$ ), and $\mathrm{E}_{\mathrm{M}}$ is measured monoterpene emission in $\mathrm{ng} \mathrm{g}^{-1} \mathrm{DW} \mathrm{min}^{-1}$. 
Monoterpene emission is temperature dependent and the equation describing this is (Guenther et al., 1993):

$$
E_{p}=E_{M} \times e^{\beta \times\left(T_{P}-T_{M}\right)}
$$

where $E_{P}$ is monoterpene emission rate at temperature $T_{P}$ (or emission on predicted temperature $\mathrm{T}_{\mathrm{P}}$ ), $\mathrm{E}_{\mathrm{M}}$ is standard (measured) emission rate at $\mathrm{T}_{\mathrm{M}}$, and $\beta$ is an empirical coefficient estimated to be $0.09 \pm 0.015 \mathrm{~K}^{-1}$ (Guenther et al., 1993).

Thus, the equation describing the combined effect of nitrogen addition and temperature derived from Equations 1 and 2 is as follows:

$$
E_{p}=\left(\left(N_{p}-N_{M}\right) \times k_{N}+E_{M}\right) \times e^{\beta \times\left(T_{\mathrm{P}}-T_{M}\right)}
$$

where $E_{P}$ is the predicted monoterpene emission in $\mathrm{ng} \mathrm{g}^{-1} \mathrm{DW} \min ^{-1}, \mathrm{~N}_{\mathrm{P}}$ is the predicted addition of nitrogen in $\mathrm{kg} \mathrm{N}_{\text {tot }}$ ha $^{-1}$ year $^{-1}$, and $\mathrm{N}_{\mathrm{M}}$ is the actual nitrogen added to the plant from which the emission is measured, $k_{N}$ is an experimentally determined, temperature dependent coefficient, and $\mathrm{E}_{\mathrm{M}}$ is the measured monoterpene emission in $\mathrm{ng}$ $\mathrm{g}^{-1} \mathrm{DW} \min ^{-1}$.

Equations 1 and 3 need to be further validated experimentally. The empirical coefficient $k_{N}$ is temperature and species dependent. Equation 2 can be used to estimate monoterpene emissions at different temperatures, other than $26^{\circ} \mathrm{C}$, for each nitrogen treatment. Using the $k_{N}$ values of different temperatures (obtained from Equation 2), a generic $k_{N}$ for young Scots pines may be described as:

$$
k_{N}=0.08 \times e^{\beta \times T_{P}}
$$

However, $k_{N}$ may be species specific and may also depend on phenology and the age of the tree, so further experiments are needed in order to provide corrections to the model. The equation also assumes that temperature and nitrogen addition have independent cumulative effects, and that $\beta$ is constant for each fertiliser group, which also needs to be experimentally confirmed in future.

The difference between the baseline emission of the controls from two experiments (NPK and urea) can be explained by differences in the initial nitrogen content in the growth medium. The first experiment had $0.28 \%$, and the second $0.51 \%$ of total $\mathrm{N}$, corresponding to 2.2 and $4.3 \mathrm{ng} \mathrm{g}^{-1} \mathrm{DW} \mathrm{min}{ }^{-1}$, respectively. The large flux variations, as observed within the treatment groups (Figure 3, Figure 6), can be explained as a result of genetic variability or small variations in environmental factors during the growth (differences in soil bacteria, mycorrhizal association, etc.).

Conifers are adapted to nutrient-poor soils, and the introduction of fertilizer leads to nutrient disbalance, affects mycorrhizal colonization, causes subcellular-level changes and makes virus infections more likely (Arnebrant and Söderström, 1992; Högberg et al., 2006; Soikkeli and Kärenlampi, 1984). Under certain circumstances these mechanisms may serve as additional stress factors that indirectly (as a consequence of nutrient addition) affect monoterpene emission, increasing the flux variation between and within the treatment groups. However, occurrence of these indirect factors and their influence on monoterpene emission should be confirmed experimentally. 
In previous work, it has been suggested that the monoterpene blend is genetically controlled by only a few genes (possibly monogenetic), and that there is high polarization (chemotype differentiation) between trees predominantly emitting $\alpha$-pinene or 3-carene (Bäck et al., 2012). Different monoterpenes have different secondary aerosol yields, which can affect the rate of cloud formation, thus any change in monoterpene composition in the troposphere might have a significant on our climate (Hoffmann et al., 1997; Lee et al., 2006). However, both GC-MS and TD-GC-MS data showed no significant change in monoterpene composition (blend) either in tissue or emitted from plants that could be attributed to the treatment in these studies.

GC-MS data also showed that fertilizer treatment did not affect monoterpene content in the pine needles (Figure 8). This may suggest that young Scots pines either emit freshly synthesised excess monoterpenes generated by high nutrient availability or the monoterpenes might be stored but not in the leaf tissue. However, this needs to be addressed in future research using isotope labelling.

As the amount of fertilizer used here is equivalent to the annual amount of $\mathrm{N}$ deposition in many areas in Europe and the world, it can be concluded that one of the most important factors already affecting monoterpene emission globally might be due to nitrogen deposition. Furthermore, the emission rate of monoterpenes in the boreal and temperate zone may increase as a consequence of higher nitrogen deposition, which could affect our climate globally. Trees in urban areas (parks, river banks etc.), where more nitrogen deposition is expected may be affected the most. However, further research in this area is needed with a focus on more complete species specific measurements of VOC emissions, modelling and upscaling.

Acknowledgements. DM and RG gratefully acknowledge the Proton Ionization Molecular Mass Spectrometry (PIMMS) Initial training network (ITN) supported by the European Commission's $7^{\text {th }}$ Framework Programme under Grant Agreement Number 287382. DB acknowledges the award of a studentship from NERC (NE/K008110/1). We also acknowledge Christopher Mayhew for instrumentation support.

\section{REFERENCES}

[1] Aalto, J., Kolari, P., Hari, P., Kerminen, V.-M., Schiestl-Aalto, P., Aaltonen, H., Levula, J., et al. (2014): New foliage growth is a significant, unaccounted source for volatiles in boreal evergreen forests. - Biogeosciences 11:1331-1344.

[2] Aalto, J., Porcar-Castell, A., Atherton, J., Kolari, P., Pohja, T., Hari, P., Nikinmaa, E., et al. (2015): Onset of photosynthesis in spring speeds up monoterpene synthesis and leads to emission bursts. - Plant, Cell \& Environment 38:2299-2312.

[3] Arnebrant, K., Söderström, B. (1992): Effects of different fertilizer treatments on ectomycorrhizal colonization potential in two Scots pine forests in Sweden. - Forest Ecology and Management 53:77-89.

[4] Arneth, A., Monson, R.K., Schurgers, G., Niinemets, Ü., Palmer, P.I . (2008): Why are estimates of global terrestrial isoprene emissions so similar (and why is this not so for monoterpenes)? - Atmospheric Chemistry and Physics 8: 4605-4620.

[5] Bäck, J., Aalto, J., Henriksson, M., Hakola, H., He, Q., Boy, M. (2012): Chemodiversity of a Scots pine stand and implications for terpene air concentrations. - Biogeosciences 9: 689-702. 
[6] Blande, J.D., Turunen, K., Holopainen, J.K. (2009): Pine weevil feeding on Norway spruce bark has a stronger impact on needle VOC emissions than enhanced ultraviolet-B radiation. - Environmental Pollution 157: 174-180.

[7] Bobbink, R., Hicks, K., Galloway, J., Spranger, T., Alkemade, R., Ashmore, M., Bustamante, M., Cinderby, S., Davidson, E., Dentener, F., Emmett, B., Erisman, J-W., Fenn, M., Gilliam, F., Nordin, A., Pardo, L., De Vries, W. (2010): Global assessment of nitrogen deposition effects on terrestrial plant diversity: a synthesis. - Ecological Applications 20: 30-59.

[8] British Standards Institute (2001): Soil Improvers and Growing Media. Determination of Nitrogen. Modified Kjeldahl Method. - B S I Standards.

[9] Brix, H. (1971): Effects of Nitrogen Fertilization on Photosynthesis and Respiration in Douglas-Fir. - Forest Science 17: 407-414.

[10] Cappellin, L., Karl, T., Probst, M., Ismailova, O., Winkler, P.M., Soukoulis, C., Aprea, E., et al. (2012): On Quantitative Determination of Volatile Organic Compound Concentrations Using Proton Transfer Reaction Time-of-Flight Mass Spectrometry. Environmental Science \& Technology 46:2283-2290.

[11] Guenther, A., Karl, T., Harley, P., Wiedinmyer, C., Palmer, P.I., Geron, C. (2006): Estimates of global terrestrial isoprene emissions using MEGAN (Model of Emissions of Gases and Aerosols from Nature). - Atmospheric Chemistry and Physics 6: 3181-3210.

[12] Guenther, A.B., Zimmerman, P.R., Harley, P.C., Monson, R.K., Fall, R. (1993): Isoprene and monoterpene emission rate variability: Model evaluations and sensitivity analyses. Journal of Geophysical Research: Atmospheres 98:12609-12617.

[13] Hoffmann, T., Odum, J.R., Bowman, F., Collins, D., Klockow, D., Flagan, R.C., Seinfeld, J.H. (1997): Formation of Organic Aerosols from the Oxidation of Biogenic Hydrocarbons. - Journal of Atmospheric Chemistry 26: 189-222.

[14] Högberg, P., Houbao, F., Quist, M., Binkley, D., Tamm, C.O. (2006): Tree growth and soil acidification in response to 30 years of experimental nitrogen loading on boreal forest. - Global Change Biology 12: 489-499.

[15] Holopainen, J.K., Gershenzon, J. (2010): Multiple stress factors and the emission of plant VOCs. - Trends in Plant Science 15: 176-184.

[16] Lee, A., Goldstein, A.H., Keywood, M.D., Gao, S., Varutbangkul, V., Bahreini, R., Ng, N.L., Flagan, R.C., Seinfeld, J.H. (2006): Gas-phase products and secondary aerosol yields from the ozonolysis of ten different terpenes. - Journal of Geophysical Research: Atmospheres 111: D07302.

[17] Loreto, F., Barta, C., Brilli, F., Nogues, I. (2006): On the induction of volatile organic compound emissions by plants as consequence of wounding or fluctuations of light and temperature. - Plant, Cell and Environment 29: 1820-1828.

[18] Loreto, F., Schnitzler, J.-P. (2010): Abiotic stresses and induced BVOCs. - Trends in Plant Science 15:154-166.

[19] Materić, D., Bruhn, D., Turner, C., Morgan, G., Mason, N., and Gauci, V. (2015): Methods in Plant Foliar Volatile Organic Compounds Research. - Applications in Plant Sciences. 3: 1500044.

[20] Peñuelas, J., Llusià, J. (2001): The Complexity of Factors Driving Volatile Organic Compound Emissions by Plants. - Biologia Plantarum 44: 481-487.

[21] Peñuelas, J., Staudt, M. (2010): BVOCs and global change. - Trends in Plant Science 15: 133-144.

[22] Räisänen, T., Ryyppö, A., Kellomäki, S. (2009): Monoterpene emission of a boreal Scots pine (Pinus sylvestris L.) forest. - Agricultural and Forest Meteorology 149: 808-819.

[23] Soikkeli, S., Kärenlampi, L. (1984): The effects of nitrogen fertilization on the ultrastructure of mesophyll cells of conifer needles in northern Finland. - European Journal of Forest Pathology 14: 129-136.

[24] Soja, A.J., Tchebakova, N.M., French, N.H.F., Flannigan, M.D., Shugart, H.H., Stocks, B.J., Sukhinin, A.I., Parfenova, E.I., Chapin, I. F.S., Stackhouse, J. P.W. (2007): Climate- 
induced boreal forest change: Predictions versus current observations. - Global and Planetary Change 56: 274-296.

[25] Tani, A., Hayward, S., Hewitt, C.N. (2003): Measurement of monoterpenes and related compounds by proton transfer reaction-mass spectrometry (PTR-MS). - International Journal of Mass Spectrometry 223-224: 561-578.

[26] Thoss, V., O'Reilly-Wapstra, J. and Iason, G.R. (2007): Assessment and Implications of Intraspecific and Phenological Variability in Monoterpenes of Scots Pine (Pinus sylvestris) Foliage. - Journal of Chemical Ecology 33:477-491.

[27] Tingey, D.T., Manning, M., Grothaus, L.C., Burns, W.F. (1980): Influence of Light and Temperature on Monoterpene Emission Rates from Slash Pine. - Plant Physiology 65: 797-801.

[28] Yassaa, N., Song, W., Lelieveld, J., Vanhatalo, A., Baeck, J., Williams, J. (2012): Diel cycles of isoprenoids in the emissions of Norway spruce, four Scots pine chemotypes, and in Boreal forest ambient air during HUMPPA-COPEC-2010. - Atmospheric Chemistry and Physics 12: 7215-7229

[29] Yuan, J.S., Himanen, S.J., Holopainen, J.K., Chen, F., Stewart, J.C.N. (2009): Smelling global climate change: mitigation of function for plant volatile organic compounds. Trends in Ecology and Evolution 24: 323-331. 